\title{
2006년 개발협력보고서의 일반 공개
}

\section{OECD 사무국은 2.22(목) 2006년 개발협} 력보고서(Development Cooperation Report)를 언론에 공개하였음.

※ 2006년 개발협력 보고서는 KOICA 홈페이지에 게시되어 있습니다.

( https://www.koica.go.kr/ -> 정보센터-> 분야 별 정보-> 연번 99 )

\section{가. 보고서 개요}

- 매년 $\mathrm{DAC}$ 의장이 제출하는 개발협력보고서 는 전년도 개발원조의 규모, 당해 연도 $\mathrm{DAC}$ 의 개발원조 관련 업무 실적 및 개발원조의 세계 적 동향을 종합한 것으로 이사회의 승인을 거 쳐 일반에 공개

- 2006 개발협력보고서는 (1) DAC 의장의 종합 적인 평가, (2) 무역을 위한 원조, (3) 원조효과
에 관한 파리선언의 이행 모니터링에 대한 설 문조사 결과, (4) $\mathrm{OECD}$ 회원국의 공적개발원 조(ODA) 공여 실적 등의 4 개 부분으로 구성

\section{나. 보고서의 일반 공개 관련 논란}

a 지난 1.11 개최된 이사회에서 회원국들은 2006 개발협력보고서의 일반공개 문제에 대 해서 논의하였으나, 나이지리아의 부채환매 (할인액 약 31 억불)를 ODA 포함시킬지에 대해 의견이 양분되었으며, 사이프러스의 ODA가 보고서에 최초로 포함된데 대해 터키가 문제 제기함으로써 공개여부를 결정하지 못함.

- 2.5 개최된 이사회는 사이프러스의 지위에 대 한 터키와 그리스간의 대립 관련, 터키와 $\mathrm{EU}$ 회원국의 입장을 각주로 보고서에 추가하는 것 을 전제로 하여 동문서의 공개를 승인하였음. 
- 나이지리아에 대한 부채 환매에 대해서는 부 채환매가 2006년도에 이루어졌기 때문에 2005년도 ODA 통계에는 영향이 없으므로 나이지리아 부채환매 관련 부분에 관한 회원 국간 논란을 소개하는 부분을 보고서에 포함 키로 함.

- 금번 발표된 2006 개발협력보고서 최종본에 서는 회원국의 요청에 따라 일부 통계가 수정 되었음.
- DAC 회원국은 2004년말 발생 인도양 쓰나미 피해국에 대해 22 억불 원조 제공

- 인도적 원조는 쓰나미 지원으로 인해 87억불 로 증가

- 2005년도 대규모 DAC ODA 수원국

- 이라크 129 억불, 나이지리아 31.6 억불, 중국 26.8 억불, 아프간 19 억불, 인도네시아 18.7 억불 순

\section{2) OECD 회원국의 원조 실적}

\section{2006 년 개발협력보고서의 주요내용}

\section{가. OECD 회원국의 ODA 공여 실적 및 평가}

\section{1) 2005년 ODA 개요}

- DAC 회원국의 2005 년도 ODA 총액은 1,068 억불로 전년도 대비 $31.4 \%$ 증가

- 회원국 GNI의 0.33\%에 해당 (2004년도는 GNI의 $0.26 \%)$

※U 회원국의 $\mathrm{ODA}$ 평균은 $\mathrm{GNI}$ 의 $0.44 \%$ 에 해당

- 이라크와 나이지리아에 대한 부채탕감 (파리 클럽의 결정)

- DAC 회원국은 이라크에 대해 140 억불, 나이 지리아에 대해 50 억불의 부채를 탕감
- 원조 규모는 미국, 일본, 영국, 프랑스, 독일 순이며, UN의 ODA 목표치 GNI의 $0.7 \%$ 를 상 회하는 국가는 덴마크, 룩셈부르크, 화란, 노 르웨이, 스웨덴 등 5 개국

- 미국의 2005년도 순ODA는 276억불로 전년 대비 $36.5 \%$ 증가

- GNI의 0.22\%(2004년 0.17\%)로 1986년 이 래 최고 수준

- 부채탕감외에 이라크 재건원조 35 억불, 아 프간 재건원조 15 억불, Sub-Sahara 아프리 카 원조 42 억불 등

- 일본의 순ODA는 131 억불, $\mathrm{GNI}$ 의 $0.28 \%$ 로 증가 (전년도 대비 $51.7 \%$ 증가)

- $\mathrm{EU}$ 회원국 15 개국의 총ODA는 557 억불로 
$27.9 \%$ 증가하여 GNI의 $0.44 \%$ 에 해당하며 주 요 증가 요인은 부채탕감에 기인

- Non-DAC OECD 회원국의 실적 : 총 15 억불

- 한국의 $\mathrm{ODA}$ 는 7.52 억불로 전년대비 $78 \%$ 증가(GNI의 $0.1 \%)$

- 기타 터키 6.01억불, 폴란드 2.05억불, 체크 1.35 억불, 헝가리 1 억불 등 기록

※ 기타 2005년도 ODA로서는 중동기금으로 부터 25 억불 및 중국, 인도 등 신흥공여국 등으로 부터의 약 30 억불이 있음.

\section{3) 향후 ODA의 전망}

- 부채탕감액의 감소로 DAC 회원국의 2006년 및 2007년 ODA는 2005년도 수준보다 감소 할 것으로 예상

- DAC 회원국의 2010 년도 목표 1300 억불 달성 을 위해서는 2008-2010년간 연 10\%의 ODA 증가가 필요
- 전세계 $\mathrm{ODA}$ 총액에서 $\mathrm{DAC}$ 회원국이 차지 하는 비중은 점차 감소할 것이나, 2015년까 지 여전히 총 $\mathrm{ODA}$ 의 $90 \%$ 선을 유지

\section{나. 우리나라 관련 사항}

- 2005년도 ODA 총액은 7.52억불로 전년대비 $78 \%$ 증가하여 $\mathrm{GNI}$ 의 $0.1 \%$ 에 해당(2004년 4.23 억불 $\mathrm{GNI}$ 의 $0.06 \%)$

- 이라크에 대한 양자원조 증가 및 세계은행, 지역개발은행 특별기금에 대한 대규모 공여 (약 2억불)에 기인

- 한국은 2010 년까지 $\mathrm{DAC}$ 회원국 가입 의사 표명

- 2006년도 3 개 혁신적 재원조달 방안중의 하 나인 항공권에 대한 개발기금을 부과키로 한 19 개국에 한국 포함. 